16. Bobyleva M. P. Razvitie printsipov dokumentooborota pri perekhode ot bumazhnogo k elektronnomu vzaimodeystviyu // Deloproizvodstvo. 2012. No. 2. URL: http://www.top-personal.ru/ officeworkissue.html?224

17. Tetrvak D. Dokumentatsiya sistemy kachestva. Komu ona nuzhna? 2008. URL: http://www.businessstudio.com.ua/info/articles. php?ELEMENT ID=11430
Chaikovska Olena, PhD, Associate Professor, Head of the Department of Computer Sciences, Kyiv University of Culture and Arts, Ukraine, e-mail: lena@knukim.edu.ua, ORCID: https://orcid.org/ 0000-0001-7769-1004

Stolyarchuk Irina, PhD, Senior Lecturer, Department of Computer Sciences, Kyiv University of Culture and Arts, Ukraine, e-mail irina77st@gmail.com, ORCID: https://orcid.org/0000-0002-2536-6696

\title{
Kovtun T., DEVELOPMENT OF METHODICAL Smokova T. APPROACH TO THE ANALYSIS OF INTEGRATION RISKS IN THE PROJECT OF CREATION OF THE LOGISTICS CENTER
}

Об'єктом дослідження є проект логістичного центру, який розглядається як організаційно та виробничо інтегрована складна система, основним завданням якої є забезпечення умов для інтегращії різноманітних об’єктів логістичної та супутньої інфраструктури на одній території. Це надає можливість поліпшення переміщення логістичних потоків.

Одним з найбільших проблемних місць є відсутність проектно-орієнтованого підходу при створенні логістичного иентру, який характеризується великою кількістю учасників, що змінюється на протязі його життєвого циклу. Це призводить до виникнення інтеграційних проектних ризиків, для запобігання яких необхідно розробити підхід до якісного аналізу ризиків, що враховує специфічні особливості об'єкту дослідження.

В ході дослідження визначено поняття «інтеграційного проектного ризику». А також розроблено послідовність якісного аналізу інтеграційних ризиків в проекті створення логістичного центру, яка полягає у використанні методів менеджменту якості, а саме: аналізу Парето, $A B C$-аналізу та причинно-наслідкового аналізу Ісікави. Застосування методів якісного аналізу здійснюється у логічній послідовності. Вихідні дані, що отримані при проведенні попереднвого виду аналізу, є вхідними для наступного етапу дослідження.

Отримані результати якісного аналізу ризику дозволяють на початковій стадії проекту збільшити вплив на його результати завдяки зниженню ступеню інтеграційних ризиків. Зокрема, аналіз Парето пропонується використовувати для виявлення основних причин виникнення інтегращійних ризиків проекту створення логістичного центту. АВС-аналіз дозволяє виділити учасників проекту, що мають найбільшу кількість інтеграційних зв'язків. Отже вихід такого учасника з проекту принесе найбільші порушення інтеграції між елементами системи. Причинно-наслідковий аналіз Ісікави дозволяє виявити причини розриву інтеграційних зв'язків між учасниками проекту та визначити найменш потужні інтеграційні зв'язки між учасниками.

Отже, використання запропонованої послідовності якісного аналізу дозволить виявити учасників проекту, які найбільш уразливі до впливу інтеграчійних ризиків та визначити потужність інтеграційних зв'язків між ними. Це, в свою чергу, дозволить прийняти заходи для попередження настання інтеграчійних ризиків у проекті створення логістичного центру.

Ключові слова: проект створення логістичного центру, інтеграційні ризики, якісний аналіз ризиків проекту.

\section{Introduction}

The state of the transport system is one of the indicators of the overall development of the country's economic complex, because transport, as an infrastructure branch, should evolve at rates that are ahead of other sectors of the economy and contribute fast economic and social growth in the country. The transport industry of Ukraine should meet the needs of internal, export-import transportation, the volume of which is determined by the level of development of the country's economy. In addition, Ukraine has always been one of the main transit states on the European continent, through which the general transport paths passed at all times. At present, the following international transport corridors (ITC) pass through the territory of Ukraine [1]:

- Cretan ITC No. 3: Berlin (Dresden) - Wroclaw Lviv - Kyiv;

- Cretan ITC No. 5: Venice - Trieste - Ljubljana Budapest - Bratislava - Uzhgorod - Lviv;

- Cretan ITC No. 9: Helsinki - St. Petersburg/Moscow - Kyiv - Chisinau - Bucharest - Alexandroupolis; - Europe - Asia;

- Gdansk - Odessa (the Baltic Sea - the Black Sea);

- Europe - Caucasus - Asia (TRACECA);

- ITC of the Black Sea Economic Cooperation. 
Recently, Ukraine seeks to join to the project «One Belt and One Road», initiated by the leadership of the People's Republic of China. The external conditions are in favor of the development of the transport industry in Ukraine, but in order to successfully use the existing capabilities, it is necessary that the country's transport system meets the requirements of the world transport system.

For Ukraine, integration into the world transport system is a priority strategic task, but at present there is considerable lag behind partner countries on many issues, namely:

- low quality of transport routes;

- imperfection of the regulatory and legislative framework for the implementation of international transport;

- the need for modernization of transport park;

- absence of modern objects of logistic infrastructure, etc.

The need to create modern logistics centers in Ukraine is particularly acute in recent years and requires the immediate adoption of measures for its satisfaction. But the solution to this practical task requires the availability of modern methodological support, the use of which:

- firstly, will be based on the application of modern methods of such areas of management and economics as project management, risk management, quality management, logistics;

- secondly, it will allow to take into account the spe-

cific features of the created objects.

Therefore, it is relevant to develop a methodical approach to qualitative analysis of integration project risks that arise between the project participants in the creation of a logistics center.

\section{The object of research and its technological audit}

The object of research is the project of the logistics center, which is considered as an organizational and production integrated complex system, the main task of which is provision of conditions for the integration of various objects of logistics and related infrastructure in one territory. This provides an opportunity to improve the movement of logistics flows.

In the document of the United Nations Economic Commission for Europe «Terminology of Combined Transport» is provided the following definition of the logistics center: the logistics center is a territorial association of independent companies and organizations involved in cargo transportation (e. g. transport intermediaries, shippers, carriers, customs authorities) and related services (for example, storage, maintenance and repair), which includes at least one terminal [2].

Logistics centers as objects of logistic infrastructure arose due to the expansion of logistics integration and became an integral part of the logistics systems that provide the opportunity to implement logistics integration. Consequently, the logistics center is a complex system that includes several subsystems, which are integrated by integration ties, through which it can perform logistic functions.

A modern look at the creation of a logistics center is its presentation as a project, one of the specific features of which is the large number of participants associated with integration communications, which is dynamically changing throughout its life cycle. Since the life cycle of projects for the creation of such large-scale infrastructure objects as a logistics center is rather long, it is difficult to predict the conditions for its implementation at the initial stage of the project. Uncertainty about future conditions and the specificity of an object can lead to risks associated with the integration of project participants.

One of the biggest problem areas is the lack of a project-oriented approach to creating a logistics center that is characterized by a large number of participants, which varies throughout its life cycle. This leads to the emergence of integration project risks, to prevent which it is necessary to develop an approach to qualitative risk analysis, taking into account the specific features of the object of research.

\section{The aim and objectives of research}

The aim of research is formation of methodological recommendations for conducting a qualitative analysis of integration risks in the project of creating a logistics center. To achieve this aim, the following scientific objectives are defined:

1. To determine the specific characteristics of the logistics center and the project for its creation.

2. To identify the features of the concept of «integration project risks».

3. To develop a sequence of qualitative analysis of the integration risks of the project of creation of the logistic center.

\section{Research of existing solutions of the problem}

Despite the large number of scientific works devoted to the formation and organization of the activity of objects of logistic infrastructure and the use of tools for project management and risk management [3-7]. As well as quality management in projection logistics systems, paid insufficient attention, in particular:

- the principles of creating logistics centers are covered in $[8-10]$;

- the issue of the projection of logistics centers is devoted [11];

- the mechanisms for the formation of logistic centers are defined in [12];

- the issue of works devoted to logistics risks [13-17];

- the issue of risk management in projects was highlighted in works [18-22].

The successful implementation of large-scale and complex projects requires the availability of appropriate methodological support, which will take into account the features of the created complexes. A large number of participants in the project of creating a logistics center are the reason for the emergence of integration project risks, the occurrence of which can lead to very negative consequences, even before the project is completely closed.

Therefore, it is necessary to pay special attention to this category of risks and conduct constant analysis to prevent their occurrence. It is necessary to conduct a qualitative analysis using a toolkit of known methods (Pareto chart, ABC analysis, Ishikawa chart) taking into account specific features of integration in the project. This will greatly reduce the degree of integration risks of the project, that is, increase its resistance to external or internal changes in the environment. In [24], the 
authors introduce the concept of «integration project risk», based on existing scientific concepts of logistics and project risks.

The work [24] defines the concept of «logistic risk», which does not take into account the possibility of breaking the integration ties that connect the elements of the logistics system, the emphasis is on logistics processes, operations, principles and branches of logistics. Under the logistic risks arising from the operation of the logistics center, it is appropriate to understand the possibility of occurrence of undesirable events that may lead to a violation of it as a micro-logistic system or as an element of the macro-logistic system at the expense of the rupture of the integration links of the system.

An analysis of existing definitions of project risks [18-22] has shown that modern authors rarely distinguish between «project risk» as a separate concept. Common terms such as «risk», «risk management», «risk control» are often considered. There are a large number of risk classifications, including project risks. The conducted research shows that project risks are considered as a possibility of negative consequences for the project, while the degree of influence on the project as a complex system is not specified.

From the point of view of the system approach, it is appropriate to consider the risk of adverse events that may lead to a violation of the project as a complex system and cause a deviation from the planned trajectory of its development. Deviations may occur under the influence of various factors, including those that will break the integration ties in the project.

Thus, taking into account the specific features of logistic center development projects, there was a need to consider «integration project risks», which includes all possible risks, the consequence of which is violation of integration, both logistic and project. Logistic integration solves the problems of topological, technological, informational integration; the project, in turn, is expressed in the integration of participants, processes and areas of the project. Taking into account the topics of the research, in the future let's consider the integration of project participants in the creation of a logistics center.

\section{Methods of research}

Throughout the process of scientific research, the toolkit of the project management methodology was used as the basis, since it is proposed to consider creating a logistics center as a project [23]. As a result, a complex object consisting of a large number of participants associated with integration ties is created, the analysis of which requires a systematic approach. Therefore, for the research of integration project risks, it is proposed to apply risk management methods, in particular to create a sequence and conduct a qualitative analysis of project risks [24]. In the process of carrying out qualitative analysis it is proposed to use methods of quality management, namely: Pareto chart, ABC analysis and Ishikawa chart.

\section{Research results}

To manage the integration risks, the project of the logistics center is characterized by all stages of project risk management, such as risk management planning, risk identification, risk analysis, quantitative risk analysis, and risk response planning [25]. Particular attention should be paid to qualitative risk analysis. At the stage of qualitative analysis, it is necessary to identify the sources of possible integration risks of the project, that is, to identify those project participants whose actions may lead to a breach of the integration ties in the project. To this end, it is proposed to use methods of quality management, namely: Pareto analysis, ABC analysis, Ishikawa cause-and-effect analysis (Fig. 1).

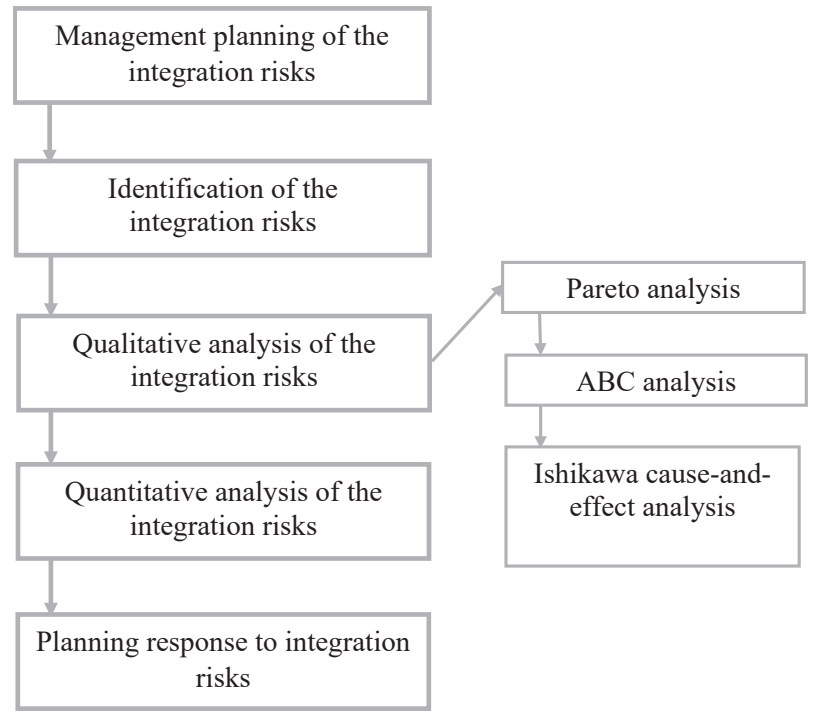

Fig. 1. Sequence of management of integration risks of the project

A method widely used in qualitative analysis of phenomena and processes is the Pareto analysis as a toolkit that allows to identify the main causes or factors that lead to the emergence of most cases being analyzed. The Pareto analysis can also be used to identify the main causes of the integration risks of a logistics center project. Input data for Pareto analysis is the set of integration ties between project participants graphically depicted as a network structure. ABC analysis is a method of qualitative analysis, which is intended to group the factors, phenomena, elements, in this case, the system «project», the degree of influence on the final result. This grouping allows to select project participants with the largest number of integration ties. Thus, the output of such a participant from the project will bring the greatest violations of integration between the elements of the system. The input data for the $\mathrm{ABC}$ analysis is Pareto analysis data.

Ishikawa cause-and-effect analysis allows to identify the reasons for the break-up of integration ties between project participants and to identify the integration ties between the most vulnerable participants, that is, the least powerful ones. The input data for chart construction are results of $\mathrm{ABC}$ analysis.

The use of the above sequence of methods of quality management in the context of management of integration risks of the project creation of the logistics center allows to obtain the following results, presented in the Table 1. 
Qualitative analysis of the integration risks of a logistics center project

\begin{tabular}{|c|c|c|c|}
\hline $\begin{array}{c}\text { Method of qualitative } \\
\text { analysis }\end{array}$ & Pareto analysis & $\mathrm{ABC}$ analysis & Ishikawa cause-and-effect analysis \\
\hline Input data & & 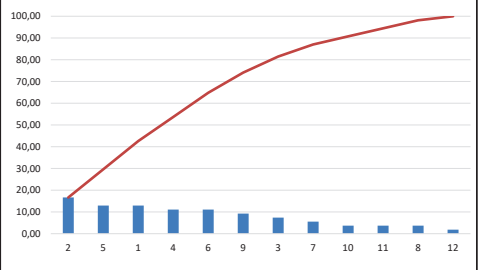 & 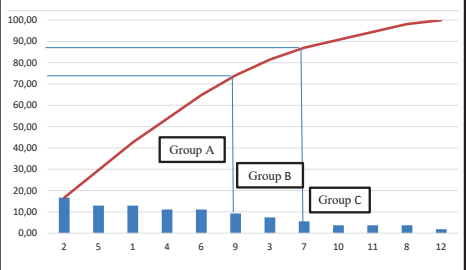 \\
\hline Obtained result & $\begin{array}{l}\text { A sequence of participants has been formed } \\
\text { based on the number of integration links } \\
\text { in the project }\end{array}$ & $\begin{array}{l}\text { The groups of project participants are struc- } \\
\text { tured according to the degree of influence } \\
\text { on integration in the project }\end{array}$ & $\begin{array}{l}\text { The causes of integration risks are revealed } \\
\text { and the power of integration links between } \\
\text { the participants is determined }\end{array}$ \\
\hline $\begin{array}{l}\text { Graphical presentation } \\
\text { of the result }\end{array}$ & 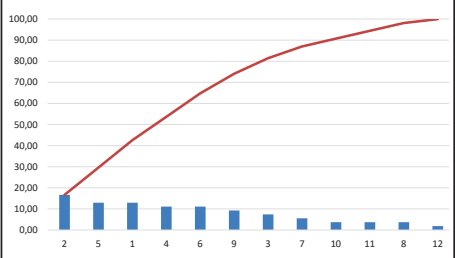 & 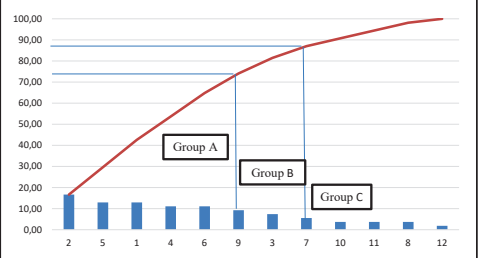 & $\sqrt[6.21]{6}$ \\
\hline
\end{tabular}

Therefore, the sequence of conducting a qualitative analysis of the integration risks of the project allows to identify the elements of the system - the project participants, the most vulnerable to the impact of integration risks and determine the capacity of the integration links between them. The process is carried out in the absence of reliable information on the conditions for the implementation of the project. Obtaining such information at the initial stages of the life cycle of the project will enable the development of preventive measures to reduce the probability of occurrence of integration risks in the project of creating a logistics center. This, in turn, will reduce the amount of funds needed to minimize their impact.

For example, let's form a system of twelve elements partners in the project of creating a logistics center. The inputs for the Pareto analysis are the network of project participants. Using the Pareto analysis tool, let's construct the Pareto chart and define the rating of the project participants by the number of integration links. Applying the tools of $\mathrm{ABC}$ analysis, let's define the importance groups for the management of integration risks:

- Group A - the most important elements of the system that have the largest number of integration links with other elements. The relative percentage of group A in the total number of elements is usually from 60 to $80 \%$. The elements of group A include participants $2 ; 5 ; 1 ; 4 ; 6 ; 9$ having a total percentage of integration ties of $74.07 \%$.

- Group B - elements that have a maximum of $20 \%$ in total. These include elements $3 ; 7$, the total share of which is $12.97 \%$.

- Group C - the least significant elements, which include participants with no more than two integration links, namely: $10 ; 11 ; 8 ; 12$. Their share accounts for $12.96 \%$ of the project [26].

Based on the results of the ABC analysis, let's construct Ishikawa chart and carry out Ishikawa causation analysis. This will reveal the reasons for the break-up of integration links between the most influential project participants.

\section{SWOT analysis of research results}

Strengths. Strengths of the research are a look at the project through the prism of an interdisciplinary approach and the creation of a sequence of qualitative risk analysis that uses not only the project management and risk management tools but also quality management. This allows to improve the qualitative analysis of the integration risks of the project of creation of the logistics center.

Weaknesses. The weakness is the need to apply expert judgment methods due to the uncertainty and the inability to obtain accurate data on the future state of the project at the beginning of the life cycle.

Opportunities. Opportunities for further researches are the improvement of methods of quantitative analysis of integration risks of the project of creation of a logistics center on the basis of the obtained results of qualitative analysis.

Threats. The threats to scientific research on this topic are the existence of a market for logistics services in turbulent environmental conditions, which can lead to negative consequences, in particular for a specific research object the project of creating a logistics center.

\section{Conclusions}

1. Specific characteristics of the logistics center are defined, which is considered as an organizational and production integrated complex system, the main task of which is provision of conditions for integration of various objects of logistic and accompanying infrastructure in one territory. Therefore, the projects of creation of logistics centers differ by a large number of participants, between whom there are integration links.

2. The peculiarities of the concept of «integration project risks», which include all possible risks, resulting in violations of integration, both logistics and project. In the work, special attention is paid to the risk of breaking integration ties between project participants in the creation of a logistics center. 
3. A sequence of qualitative analysis of the integration risks of a logistics center project has been developed, which allows the use of quality management tools, namely Pareto analysis, ABC analysis and Ishikawa causation analysis. In conditions of uncertainty, this helps to identify the most vulnerable, in terms of breaking the integration links, elements of the system «project». It is these elements that project participants need to focus on during the project implementation, since their output from the system and the breaking of integration links can lead to almost closure of the project. Thus, the proposed methodological approach will significantly reduce the impact of integration risks on the success of the project implementation of the creation of a logistics center.

\section{References}

1. Transportna polityka Ukrainy ta yii nablyzhennia do norm Yevropeiskoho Soiuzu / Syryichyk T. et al.; ed. by Svienchitski M. Kyiv: Analitychno-doradchyi tsentr Blakytnoi strichky, 2010. 102 p.

2. Terminology on combined transport // United Nations Economic Commission for Europe. 2001. URL: https://www.unece. org/index.php?id=26168

3. Sergeev V. I. Logistika v transportnom komplekse Rossii: problemy i predlozheniya // Logistika $\mathrm{v}$ transportnom komplekse RF, 2011. URL: http://www.myshared.ru/slide/955875/

4. Krikavskiy E. V. Logisticheskiy tsentr - eto uzlovoy obiekt logisticheskikh setey // Logistika: problemy i resheniya. 2008. No. 5 (18). P. 38-40.

5. Gadzhinskiy A. M. Logistika: textbook. Moscow: Dashkov i K, 2011. $481 \mathrm{p}$.

6. Stock J., Lambert D. Strategic Logistics Management. McGrawHill/Irwin, 2000. 896 p.

7. Waters D. Logistics: An Introduction to Supply Chain Management. Palgrave Macmillan, 2002. 372 p.

8. Nykyforuk O. I. Stanovlennia i funktsionuvannia transportnolohistychnoi infrastruktury v Ukraini: Abstract's PhD thesis. Kyiv, 2005. $21 \mathrm{p}$.

9. Vinogradov M. A. Upravlenie mezhregional'nym tovaroobmenom na osnove sozdaniya logisticheskikh tsentrov: na primere Rostovskoy oblasti: Abstract's PhD thesis. Rostov-na-Donu, 2007. 26 p.

10. Poliakova O. M. Formuvannia intermodalnoi transportnoi systemy Ukraini na bazi vantazhnykh transportno-rozpodilchykh kompleksiv: Abstract's PhD thesis. Kharkiv, 2005. 20 p.

11. Kontseptsiia prohramy formuvannia merezhi lohistychnykh tsentriv v systemi mizhnarodnykh transportnykh korydoriv Ukrainy / Tsvietkov Yu. M. et al. Kyiv: KUETT, 2003. 109 p.

12. Komarnytskyi I. M., Pytuliak N. S., Kohut I. V. Mekhanizmy formuvannia lohistychnykh tsentriv // Vydavnytstvo Natsionalnoho universytetu «Lvivska politekhnika». 2007. No. 582. P. 190-196.

13. Mamchyn M. M., Rusanovska O. A. Vplyv lohistychnykh ryzykiv na pidvyshchennia efektyvnosti diialnosti pidpryiemstv //
Visnyk Natsionalnoho universytetu «Lvivska politekhnika». Seriia «Menedzhment ta pidpryiemnytstvo v Ukraini: etapy stanovlennia i problemy rozvytku». 2011. No. 720. P. 45-51.

14. Rovenskikh M. V. Upravlenie riskami logisticheskoy sistemy promyshlennogo predpriyatiya: PhD thesis. Saint Petersburg, 2008. 261 p.

15. Fuchs H., Wohinz J. W. Risk management in logistics systems // Advances in Production Engineering \& Management. 2009. Vol. 4. P. 233-242.

16. Pletneva N. G. Teoriya i metodologiya upravleniya logisticheskimi sistemami v usloviyakh neopredelennosti: Abstract's PhD thesis. Saint Petersburg, 2008. 37 p.

17. Vitlinskyi V. V., Skitsko V. I. Kontseptualni zasady modeliuvannia ta upravlinnia lohistychnym ryzykom pidpryiemstva // Problemy ekonomiky. 2013. No. 4. P. 246-251.

18. Larson E. Project Management: The Managerial Process. McGraw Hill, 2010. 608 p.

19. Archibald R. D. Managing High-Technology Programs and Projects. John Wiley \& Sons, 2003. 416 p.

20. Boldyreva T. V., Kovtun T. A. Metodika otsenki effektivnosti investitsionnogo proekta s uchetom situatsiy riska // Metodi ta zasobi upravlinnya rozvitkom transportnikh sistem. 2003. No. 6. P. 237-255.

21. Korolkova E. M. Risk-menedzhment: upravlenie proektnymi riskami: textbook. Tambov: FGBOU VPO «TGTU», 2013. 160 p.

22. Koshelevskiy I. S. Obzor metodov upravleniya proektnymi riskami: Proceedings // Problemy sovremennoy ekonomiki. Chelyabinsk: Dva komsomol'tsa, 2012. P. 164-166.

23. Smokova T. N. The integration in projects of multimodal logistics parks // Eastern-European Journal of Enterprise Technologies. 2011. Vol. 1, No. 7 (49). P. 14-15. URL: http://journals.uran.ua/ eejet/article/view/2399

24. Kovtun T. A., Smokova T. M. Upravlinnia intehratsiinymy ryzykamy $\mathrm{v}$ proektakh multymodalnykh lohistychnykh kompleksiv // Visnyk NTU «KhPI». Seriia: Stratehichne upravlinnia, upravlinnia portfeliamy, prohramamy ta proektamy. 2016. No. 2 (1174). P. 26-30.

25. PMBOK. Rukovodstvo k Svodu znaniy po upravleniyu proektami (Rukovodstvo PMBOK). Project Management Institute, Fourteen Campus Boulevard, 2013. 589 p.

26. Kovtun T. A., Smokova T. M. Zastosuvannia instrumentariiu yakisnoho analizu ryzykiv u proekti stvorennia lohistychnoho tsentru // Visnyk Skhidnoukrainskoho natsionalnoho universytetu imeni Volodymyra Dalia. 2018. No. 2 (243). P. 122-125.

Kovtun Tetiana, PhD, Associate Professor, Department of Logistic Systems and Projects Management, Odessa National Maritime University, Ukraine, e-mail: tandem@gcn.ua, ORCID: https://orcid.org/ 0000-0002-5410-4783

Smokova Tetiana, Assistant, Department of Logistic Systems and Projects Management, Odessa National Maritime University, Ukraine, e-mail: smokova.tm@gmail.com, ORCID: https://orcid.org/00000002-0688-5677 